\title{
ANALISIS FAKTOR YANG MEMPENGARUHI KETEPATAN WAKTU PELAPORAN KEUANGAN PERUSAHAAN PROPERTY DAN REAL ESTATE DI BEI TAHUN 2011-2014
}

\author{
Muhammad Hidayatullah, Rani Eka Diansari \\ Universitas PGRI Yogyakara \\ Jl. PGRI No. 117 Sonosewu, Yogyakarta. \\ e-mail: hidayat2219@gmail.com
}

\begin{abstract}
This study aims to examine factors that influence the timeless of financial report. The independent variable of this research are profitability, firmsize, and the public ownership, while the dependent variable is timeless. The population of this research are property and real estate companies which are listed in Indonesian Stock Exchange 2011-2014. The sample in this research is taken by using purposive sampling method with some carracteristics and consist of 30 companies. This research used secondary data from www.idx.co.id and the method of analysis used logistic regression analysis. The results show that the profitability is significantly influenced to the timeless of financial report, while both the firmsize and public ownership are not significantly influenced the timeless of financial report.
\end{abstract}

Keywords: Timeless, Profitability, Firmsize, Public Ownership.

\section{Pendahuluan}

Pengaruh globalisasi ekonomi yang terjadi saat ini memberikan dampak positif dan negatif bagi perekonomian Indonesia. Besarnya jumlah produksi barang yang dihasilkan suatu perusahaan merupakan dampak nyata dari pengaruh globalisasi yang menuntut perusahaan untuk terus tumbuh dan berkembang mengikuti perkembangan zaman. Hal itu agar perusahaan tetap mampu mempertahankan eksistensinya dalam menghadapi persaingan di masa mendatang. Semakin pesatnya perkembangan perusahaan mewajibkan setiap perusahaan untuk menyajikan laporan keuangan yang sesuai dengan kondisi riil perusahaan agar sesuai dengan standar akuntansi yang berlaku (Tiza Marathani, 2013).

Pelaporan keuangan merupakan sarana bagi perusahaan untuk mengkomunikasikan berbagai informasi serta pengukuran secara ekonomi mengenai sumber daya dan kinerja yang dimiliki kepada pihak-pihak yang berkepentingan atas informasi keuangan. Informasi dikatakan bermanfaat bagi pengguna jika disampaikan tepat waktu.

Hal itu dikarenakan ketepatan waktu penyampaian pelaporan keuangan perusahaan merupakan determinan penting yang dapat dijadikan tolok ukur untuk menilai tingkat kebermanfaatan laporan keuangan. Jika dalam penyampaian laporan keuangan terjadi keterlambatan, maka manfaat dari laporan keuangan akan berkurang (IAI, 2002).

Ketepatan waktu penyampaian laporan keuangan di Indonesia telah diatur dalam Undang-Undang No. 8 tahun 1985 tentang pasar modal. Seperti dikutip dalam Suriyati (2013), undang-undang tersebut secara jelas menerangkan bahwa perusahaan diharuskan menyampaikan dan mengumumkan laporan keuangannya secara periodik dan tepat waktu. Laporan keuangan disusun sesuai dengan Prinsip Akuntansi Berlaku Umum (PABU) dan telah diaudit oleh auditor independen yang terdaftar di BAPEPAM. Tahun 1996 BAPEPAM mengeluarkan lampiran keputusan ketua BAPEPAM Nomor: Kep-BAPEPAM-80/PM/1996 yang intinya mewajibkan setiap emiten dan perusahaan publik untuk menyampaikan laporan keuangan tahunan 
perusahaan dan laporan auditor independennya kepada BAPEPAM selambat-lambatnya 120 hari setelah tanggal laporan tahunan perusahaan. Kemudian keputusan tersebut kembali diperketat dengan dikeluarkannya Kep-17/PM/2002 yang diperbaharui dengan peraturan BAPEPAM Nomor: X.K.2, lampiran keputusan ketua BAPEPAM Nomor: Kep-36/PM/2003 yang menyatakan bahwa laporan keuangan tahunan disertai dengan laporan akuntan dengan pendapat yang lazim harus disampaikan kepada BAPEPAM selambat-lambatnya pada akhir bulan ketiga (90 hari) setelah tanggal laporan keuangan tahunan.

Perusahaan yang menyajikan laporan keuangan lewat dari tanggal yang telah ditentukan akan dikenakan sanksi administratif sesuai peraturan yang berlaku. Maksud dari penyempurnaan peraturan tersebut adalah untuk membantu para investor dalam memperoleh informasi keuangan yang lebih cepat sehingga dapat dijadikan sebagai dasar acuan dalam pengambilan keputusan investasi dan penyesuaian dengan pasar modal.

Peraturan yang dikeluarkan BAPEPAM Nomor X.K.2, Lampiran Keputusan Ketua BAPEPAM dan LK No. KEP-346/BL/2011 mengharuskan semua perusahaan go public menyampaikan laporan keuangan tepat waktu, pada kenyataannya masih banyak perusahaan yang terlambat dalam menyampaikan laporan keuangan. Berdasarkan penelitianpenelitian terdahulu terdapat beberapa faktor yang diduga dapat mempengaruhi ketepatan waktu pelaporan keuangan suatu perusahaan, faktor-faktor yang digunakan dalam penelitian ini adalah profitabilitas, ukuran perusahaan, dan kepemilikan publik (Hilmi dan Ali, 2008).

Profitabilitas diduga sebagai salah satu faktor yang dapat mempengaruhi ketepatan waktu pelaporan keuangan. Profitabilitas suatu perusahaan dapat digunakan untuk mengukur kinerja perusahaan. Profitabilitas sering dijadikan patokan oleh investor dan kreditur untuk menilai sehat tidaknya perusahaan (Purwanto, 2004). Penelitian yang dilakukan oleh Sukoco (2013) dan Wijayanti (2009) menunjukkan bahwa profitabilitas berpengaruh signifikan terhadap ketepatan waktu pelaporan keuangan. Hasil penelitian tersebut berbanding terbalik dengan penelitian yang dilakukan Astuti (2007) yang menunjukkan bahwa profitabilitas tidak mempengaruhi ketepatan waktu pelaporan keuangan.

Ukuran perusahaan dapat menggambarkan besar kecilnya suatu perusahaan. Menurut penelitian yang dilakukan oleh Lenny dan Indriantoro (1999) dalam Kristina (2005) besarnya ukuran perusahaan mampu mempengaruhi investor. Sebagian besar investor masih beranggapan bahwa perusahaan berukuran besar, tingkat kestabilan keuangan perusahaan akan terjaga dan didukung oleh analisis yang kompeten, sehingga informasi dan laporan keuangan yang dihasilkan dapat meminimalkan tingkat kegagalan yang telah diperkirakan. Besarnya tingkat kestabilan keuangan yang dimiliki oleh perusahaan berukuran besar diprediksikan akan berpengaruh terhadap ketepatan waktu penyampaian laporan keuangan. Ifada (2009) melakukan penelitian mengenai pengaruh ukuran perusahaan terhadap ketepatan waktu pelaporan keuangan, hasil penelitian memberikan bukti empiris bahwa ukuran perusahaan berpengaruh signifikan terhadap ketepatan perusahaan dalam melaporkan laporan keuangan. Namun penelitian yang dilakukan oleh Awaludin dan Peni (2012) menemukan hasil yang berbeda, ukuran perusahaan yang diproksikan dengan total penjualan tidak mempengaruhi ketepatan waktu perusahaan dalam melaporkan laporan keuangan. Kepemilikan publik dapat menunjukkan besarnya jumlah saham yang dimiliki oleh masyarakat.

Kepemilikan publik yang besar bisa memberikan tekanan kepada pihak manajemen agar dapat menyajikan laporan keuangan secara tepat waktu. Hal ini didasarkan karena kinerja dan pencapaian perusahaan mendapat sorotan dari publik (Hilmi dan Ali, 2008). Penelitian yang dilakukan Sulistyo (2010) menunjukkan bahwa kepemilikan publik berpengaruh signifikan terhadap ketepatan waktu pelaporan keuangan, sesuai dengan pernyataan di atas besarnya 
kepemilikan publik memberikan tekanan kepada pihak manajemen agar tepat waktu dalam menyampaikan laporan keuangannya. Fakta sebaliknya ditemukan oleh Sukoco (2013) yang mengemukakan bahwa kepemilikan publik tidak berpengaruh terhadap ketepatan waktu pelaporan keuangan.

Peneliti termotivasi untuk melakukan penelitian mengenai faktor-faktor yang berpengaruh terhadap ketepatan waktu pelaporan keuangan dikarenakan hasil-hasil penelitian terdahulu mendapatkan hasil yang berbeda-beda atau tidak konsisten. Penelitian yang dilakukan oleh Wijayanti (2009) dan Sulistyo (2010) membuktikan bahwa profitabilitas, ukuran perusahaan, dan kepemilikan publik berpengaruh secara signifikan terhadap ketepatan waktu pelaporan keuangan perusahaan. Hasil penelitian tersebut tidak sejalan dengan penelitian Melia (2012) yang menunjukkan bahwa Profitabilitas, Ukuran Perusahaan, dan Kepemilikan Publik tidak memiliki pengaruh yang signifikan terhadap ketepatan waktu pelaporan keuangan perusahaan.

Berdasarkan latar belakang penelitian yang telah diuraikan di atas, maka judul penelitian ini adalah "Analisis Faktor yang Mempengaruhi Ketepatan Waktu Pelaporan Keuangan Perusahaan Property dan Real Estate di BEI tahun 2011-2014".

\section{Kajian Teori dan Hipotesis}

\section{Laporan Keuangan}

\section{a. Pengertian Laporan Keuangan}

Baridwan (2004) mendefinisikan laporan keuangan sebagai hasil akhir dari proses pencatatan yang merupakan suatu ringkasan dari transaksi-transaksi keuntungan yang terjadi selama tahun buku yang bersangkutan. Laporan keuangan dibuat oleh manajemen dengan tujuan untuk memenuhi tanggung jawab yang telah dibebankan oleh para pemilik perusahaan di samping itu laporan keuangan dapat juga digunakan untuk memenuhi tujuan- tujuan lain yaitu sebagai laporan kepada pihak-pihak di luar perusahaan.

Menurut Surya (2012) laporan keuangan menggambarkan pengaruh keuangan dari kejadian di masa lalu dan tidak diwajibkan untuk menyajikan informasi non keuangan. Manajemen perusahaan memikul tanggung jawab utama dalam penyusunan dan penyajian laporan keuangan. Manajemen memiliki kemampuan untuk menentukan bentuk dan tambahan informasi manajemen dan keuangan untuk memenuhi kebutuhannya sendiri dalam melaksanakan tanggung jawab perencanaan, pengendalian, dan pengambilan keputusan.

Sedangkan dalam Standar Akuntansi Keuangan (IAI, 2007) disebutkan bahwa laporan keuangan merupakan bagian dari pelaporan keuangan. Laporan keuangan yang lengkap biasanya meliputi neraca, laporan laba rugi, laporan perubahan posisi keuangan (yang dapat disajikan dalam berbagai cara, misalnya sebagai laporan arus kas atau laporan arus dana), catatan dan laporan lain serta materi penjelasan yang merupakan bagian integral dari laporan keuangan.

Pelaporan keuangan merupakan laporan keuangan ditambah dengan informasi lain yang berhubungan, yang telah disediakan oleh sistem akuntansi baik langsung maupun tidak langsung. Seperti informasi tentang sumber daya perusahaan, earning, current cost, informasi tentang prospek perusahaan yang merupakan bagian integral (Yadiati, 2007). Dikutip dalam Baridwan (2004), informasi yang harus disajikan dalam pelaporan keuangan yang dinyatakan dalam Statement of Financial Accounting Concepts (SFAC) Nomor 1 di antaranya:

1) Informasi yang disajikan harus berguna bagi investor dan kreditur yang ada dan potensial dan pemakai lainnya dalam membuat keputusan untuk investasi, pemberian kredit dan keputusan lainnya. Informasi dalam laporan keuangan yang dihasilkan harus memadai untuk mereka yang mempunyai 
pengetahuan cukup tentang kegiatan dan usaha perusahaan, peristiwa-peristiwa ekonomi, serta bermaksud untuk menelaah informasi tersebut secara sungguh-sungguh.

2) Informasi yang disajikan harus berguna bagi investor dan kreditur yang ada dan yang potensial dan pemakai lainnya untuk menaksir jumlah, waktu, dan ketidakpastian dari penerimaan uang di masa yang akan datang yang berasal dari deviden atau bunga dari penerimaan uang yang berasal dari penjualan, pelunasan, atau jatuh temponya surat-surat berharga atau pinjaman-pinjaman.

3) Informasi yang disajikan harus menunjukkan sumber-sumber ekonomi dari suatu perusahaan, klaim atas sumber-sumber tersebut (kewajiban perusahaan untuk mentransfer sumbersumber ke perusahaan lain dan ke pemilik perusahaan), pengaruh dari transaksi-transaksi, kejadian-kejadian, dan keadaan yang mempengaruhi sumbersumber dan klaim atas sumber tersebut.

\section{b. Komponen-Komponen Laporan Keuangan}

Djarwanto (2004) menyatakan pada dasarnya laporan keuangan merupakan hasil refleksi dari sekian banyak transaksi yang terjadi dalam suatu perusahaan. Transaksi-transaksi dan peristiwa-peristiwa yang bersifat finansial dicatat, digolongkan, dan diringkaskan dengan cara setepat-tepatnya dalam satuan uang, dan kemudian diadakan penafsiran untuk berbagai tujuan.

Laporan keuangan terdiri dari: neraca, laporan laba-rugi, laporan bagian laba yang ditahan atau laporan modal sendiri, dan laporan perubahan posisi keuangan atau laporan sumber dan penggunaan dana.

1) Neraca.

Laporan yang menggambarkan kondisi keuangan dari suatu perusahaan pada tanggal tertentu, umumnya pada akhir tahun pada saat penutupan buku. Neraca memuat aktiva (harta kekayaan yang dimiliki perusahaan), hutang (kewajiban perusahaan untuk membayar dengan uang atau aktiva lain kepada pihak lain pada waktu tertentu yang akan datang), dan modal sendiri (kelebihan aktiva di atas hutang).

2) Laporan laba-rugi.

Laporan yang menunjukkan pendapatan-pendapatan dan biaya yang timbul dari suatu perusahaan dalam periode tertentu. Laporan ini memperlihatkan adanya pendapatan bersih atau kerugian bersih sebagai hasil dari operasi perusahaan selama periode tertentu (umumnya satu tahun).

3) Laporan bagian laba yang ditahan.

Laporan ini digunakan pada perusahaan yang berbentuk perseroan dan menunjukkan suatu analisis perubahan besarnya bagian laba yang ditahan selama jangka waktu tertentu. Sedangkan laporan modal sendiri diperuntukkan bagi perusahaan perseroan dan bentuk persekutuan, meringkaskan perubahan besarnya modal pemilik atau pemilik-pemilik selama periode tertentu.

4) Laporan perubahan posisi keuangan.

Laporan ini memperlihatkan aliran modal kerja selama periode tertentu. Sumber-sumber mengenai perolehan modal kerja, penggunaan, dan pengeluaran modal kerja selama periode tertentu dimuat dalam laporan ini.

\section{c. Pengguna Laporan Keuangan}

Laporan keuangan dibuat karena adanya kepentingan dari pihak yang membutuhkan informasi bersangkutan dengan perusahaan. Berikut pengguna laporan keuangan dan pentingnya informasi keuangan dilihat dari masing-masing perspektif (Murhadi, 2013):

1) Pemegang Saham, Investor, dan Analisis Sekuritas.

Pihak utama yang membutuhkan 
informasi mengenai kondisi dari keuangan perusahaan adalah pemegang saham dan investor. Pihak ini sangat bervariasi mulai dari pemegang saham dan investor ritel yang relatif tidak memiliki informasi dan tenaga ahli yang baik dalam menilai kinerja suatu perusahaan. Pihak ini tidak hanya membuat keputusan-keputusan untuk membeli, mempertahankan atau menjual suatu saham perusahaan, tetapi juga untuk melakukan tindakan pembelian atau penjualan tersebut.

2) Manajer.

Pihak manajer membutuhkan laporan keuangan mengenai kinerja perusahaan dan karena adanya batasan-batasan kontrak yang perlu ditaati. Manajer membutuhkan informasi terkait kinerja perusahaan dalam rangka menentukan kelayakan paket kompensasi bagi pihak manajemen dan karyawan dalam suatu perusahaan. Selain itu, perusahaan yang menggunakan pendanaan dari kreditur seperti perbankan akan menandatangani kontrak-kontrak yang harus dilakukan oleh pihak manajemen seperti menjadi likuiditas. Informasi laporan keuangan juga digunakan oleh manajer untuk membuat keputusan yang terkait investasi, pembiayaan, dan operasional perusahaan.

3) Karyawan.

Informasi laporan keuangan tidak hanya berisi informasi mengenai kondisi keuangan saat ini, namun juga mampu menggambarkan potensi di masa mendatang. Karyawan membutuhkan informasi kondisi keuangan tidak hanya untuk keperluan kompensasi, namun juga terkait dengan masa depan mereka termasuk pensiun di dalamnya.

4) Supplier dan Kreditur.

Informasi kondisi keuangan perusahaan sangat penting bagi pemasok bahan baku, kepentingan tersebut berkaitan dengan material yang telah mereka berikan kepada perusahaan dan kelangsungan pembayaran utang perusa- haan kepada pemasok tersebut.

Hal ini juga sama dengan kreditur perusahaan, dimana pihak kreditur seperti bank telah memberikan dananya kepada perusahaan dan harus dapat memastikan bahwa kredit yang telah diberikan tersebut akan kembali dengan lancar. Untuk itu biasanya pihak kreditur akan mengikat perusahaan dengan perjanjian kredit yang akan memberikan batasan-batasan yang harus dipenuhi oleh perusahaan.

5) Pelanggan.

Hubungan baik antara pelanggan dan perusahaan harus tetap terjaga. Hubungan baik dengan pelanggan akan memberikan manfaat bagi perusahaan itu sendiri. Pelanggan membutuhkan informasi mengenai kondisi keuangan perusahaan terkait dengan kelangsungan produk yang telah dibeli dari perusahaan seperti garansi. Pelanggan tidak akan membeli suatu produk yang ditawarkan dari perusahaan yang akan mengalami masalah di masa mendatang.

6) Pemerintah.

Pemerintah membutuhkan informasi keuangan terkait dengan pajak yang nantinya akan dibayarkan oleh perusahaan. Pemerintah tidak hanya membutuhkan informasi tentang besarnya pajak yang dibayarkan, namun sebagai regulator pemerintah juga perlu informasi mengenai besarnya pajak yang akan dikenakan ke dunia usaha.

\section{Ketepatan Waktu Pelaporan Keuangan}

Laporan keuangan yang dibuat harus memenuhi empat karakteristik kualitatif yang merupakan ciri khas yang bisa membuat informasi laporan keuangan berguna bagi para pemakainya hal ini disesuaikan Berdasarkan Kerangka Dasar Penyusunan dan Penyajian Laporan Keuangan Standar Akuntansi Keuangan. Keempat karakteristik tersebut yaitu dapat dipahami, relevan, andal, dan dapat diperbandingkan, namun pada kenyataannya untuk mendapatkan informasi 
yang relevan tersebut terdapat beberapa kendala di antaranya adalah ketepatan waktu (Hilmi dan Ali, 2008).

Tepat waktu diartikan bahwa informasi harus disampaikan sedini mungkin untuk dapat digunakan sebagai dasar untuk membantu dalam pengambilan keputusan-keputusan ekonomi dan untuk menghindari tertundanya pengambilan keputusan tersebut (Baridwan, 2004). Keterlambatan mengenai pelaporan keuangan perusahaan terjadi apabila perusahaan menyampaikan laporan keuangan lewat dari tanggal yang telah ditentukan sesuai dengan peraturan yang ditentukan BAPEPAM (Saleh, 2004).

\section{Profitabilitas}

Profitabilitas menggambarkan keberhasilan perusahaan untuk dapat menghasilkan laba melalui semua kemampuan, dan sumber yang ada seperti kegiatan penjualan, kas, modal, jumlah karyawan, jumlah cabang dan sebagainya (Harahap, 2007). Rasio profitabilitas dapat dilihat pada Return on Assets (ROA) yang dimiliki perusahaan yang digunakan untuk membandingkan antara laba bersih dan total asset sehingga dapat diketahui kemampuan perusahaan dalam menghasilkan laba. Pertumbuhan laba yang terus meningkat dari tahun ke tahun, akan memberikan sinyal yang positif mengenai kinerja perusahaan (Mariewaty dan Setyani, 2005).

\section{Ukuran Perusahaan}

Ukuran perusahaan dapat dinilai dari beberapa segi. Rachmawati (2008) mengukur besar kecilnya ukuran perusahaan pada total nilai asset. Sementara Respati (2001) dan Saleh (2004) mengukur ukuran perusahaan menggunakan market value. Semakin besar asset perusahaan maka semakin banyak modal yang ditanam, semakin banyak penjualan maka semakin banyak perputaran uang, dan semakin besar kapitalisasi pasar maka semakin besar pula perusahaan dikenal dalam masyarakat Hilmi dan Ali, 2008).

Ukuran perusahaan menjadi pengaruh apakah perusahaan dapat melaporkan laporan keuangan tepat waktu. Schwartz dan Soo (1996) dalam Respati (2001) menyatakan perusahaan yang berukuran besar lebih banyak mengetahui peraturan yang ada, sehingga perusahaan besar mungkin memiliki kecenderungan dapat melaporkan laporan keuangan tepat waktu.

\section{Kepemilikan Publik}

Hilmi dan Ali (2008) mendefinisikan kepemilikan publik adalah kepemilikan masyarakat umum (bukan institusi yang signifikan) terhadap saham perusahaan publik. Adanya konsentrasi kepemilikan dari masyarakat luar menimbulkan pengaruh yang berdampak pada berubahnya pengelolaan perusahaan yang semula berjalan sesuai keinginan menjadi memiliki keterbatasan. Terkait hal tersebut diperkirakan perusahaan dengan kepemilikan publik yang besar cenderung tepat waktu dalam menyampaikan laporan keuangan.

Struktur kepemilikan perusahaan yang dimiliki oleh pihak luar biasanya mempunyai persentase kepemilikan lebih dari $50 \%$ sehingga dapat dikatakan pemilik perusahaan dari pihak luar mempunyai kekuatan yang besar dalam mempengaruhi kondisi dan hasil kinerja perusahaan (Awaludin dan Peni, 2012).

Berdasarkan uraian dari tinjauan pustaka di atas maka dapat rangkum dalam sebuah kerangka pemikiran sebagai berikut:

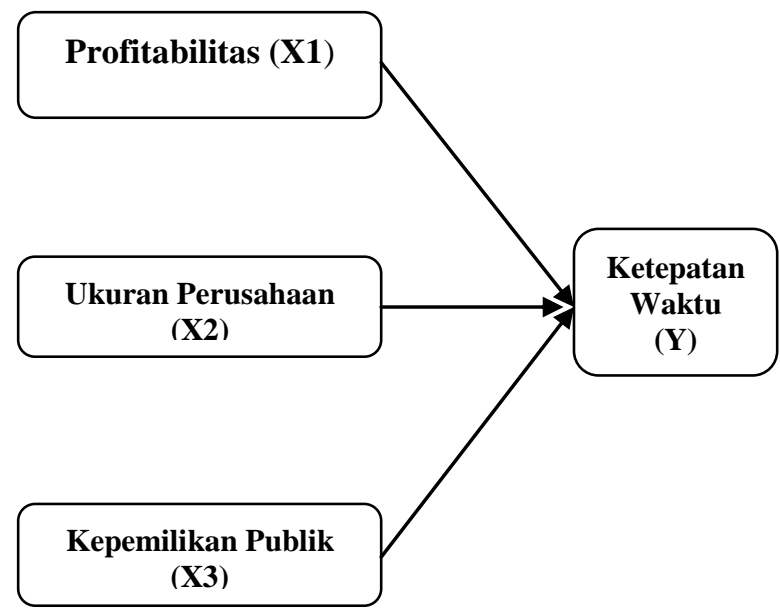

Gambar 1. Kerangka Pemikiran Teoritis. 


\section{Metode Penelitian}

\section{Populasi dan sampel}

Populasi dalam penelitian ini adalah perusahaan sektor property dan real estate yang terdaftar di Bursa Efek Indonesia tahun 2011-2014 dengan jumlah 30 perusahaan. Pengambilan sampel dalam penelitian ini menggunakan metode purposive sampling. Metode purposive sampling merupakan metode dengan menggunakan pemilihan sampel yang tidak acak, informasi dari metode ini diperoleh dengan pertimbangan tertentu (Indriantoro dan Supomo, 2001).

\section{Variabel Penelitian}

a. Variabel Dependen.

Menurut Indriantoro dan Supomo (2001) variabel dependen merupakan variabel yang berpengaruh dan mampu menjelaskan variabel-variabel lain. Variabel dependen yang digunakan dalam penelitian ini adalah ketepatan waktu, kategori 0 untuk perusahaan yang tidak tepat waktu dan kategori 1 untuk perusahaan yang tepat waktu.

b. Variabel Independen.

Menurut Indiantoro dan Supomo (2001) variabel independen merupakan variabel yang dapat dijelaskan atau dipengaruhi oleh variabel yang lain. Variabel independen yang digunakan dalam penelitian ini adalah Profitabilitas, Ukuran perusahaan, dan Kepemilikan Publik.

\section{Model dan Hipotesis Penelitian}

Hipotesis dalam penelitian ini adalah:

H1: Profitabilitas berpengaruh signifikan terhadap ketepatan waktu penyampaian pelaporan keuangan.

H2: Ukuran Perusahaan berpengaruh signifikan terhadap ketepatan waktu penyampaian pelaporan keuangan.

H3: Kepemilikan Publik berpengaruh signifikan terhadap ketepatan waktu penyampaian pelaporan keuangan.

\section{Definisi Operasional}

\section{Ketepatan Waktu Pelaporan Keuangan}

Ketepatan waktu pelaporan keuangan adalah rentang waktu mengumumkan laporan keuangan tahunan yang telah diaudit kepada publik sejak tanggal tutup buku perusahaan (31 Desember) sampai tanggal penyerahan ke BAPEPAM-LK (Rachmawati, 2008). Peraturan Nomor. X.K.2, Lampiran Keputusan Ketua BAPEPAM dan LK Nomor. KEP-346/BL/2011 laporan keuangan tahunan wajib disampaikan kepada BAPEPAM dan LK serta diumumkan kepada masyarakat paling lambat pada akhir bulan ketiga setelah tanggal laporan keuangan tahunan.

Ketepatan waktu dalam penelitian ini diukur dengan dummy variabel, kategori 1 untuk perusahaan yang tepat waktu dan kategori 0 untuk perusahaan yang tidak tepat waktu (Hilmi dan Ali, 2008). Tepat waktu diartikan perusahaan wajib melaporkan laporan keuangan paling lambat tanggal 31 Maret dan diberi angka 1, sedangkan untuk perusahaan yang tidak tepat waktu adalah perusahaan yang melaporkan pelaporan keuangan lewat dari tanggal 31 Maret dan diberikan angka 0 .

\section{Profitabilitas}

Profitabilitas dapat diukur dengan menggunakan rasio return on asset (ROA) dan return on equity (ROE). Indikator yang digunakan dalam penelitian ini adalah return on asset (ROA). Return on assets (ROA) merupakan rasio yang terpenting di dalam rasio profitabilitas (Ang, 1997 dalam Sulistyo 2010).

$$
\text { Return On Asset }=\frac{\text { Net Income }}{\text { Total Asset }} \times 100
$$

\section{Ukuran Perusahaan}

Ukuran perusahaan dapat dihubungkan dengan ketepatan waktu penyampaian laporan keuangan. Ukuran perusahaan dapat 
dinilai dari beberapa segi. Besar kecilnya ukuran perusahaan dapat didasarkan pada total nilai aset, total penjualan, kapitalisasi pasar, jumlah tenaga kerja dan sebagainya. Semakin besar nilai item-item tersebut maka semakin besar pula ukuran perusahaan itu (Awaludin dan Peni, 2012). Ukuran perusahaan pada penelitian ini diukur menggunakan total asset yang dimiliki oleh perusahaan (Hilmi dan Ali, 2008).

\section{Kepemilikan Publik}

Struktur kepemilikan perusahaan dapat disebut juga sebagai struktur kepemilikan saham, yaitu suatu perbandingan antara jumlah saham yang dimiliki oleh pihak dalam atau manajemen perusahaan (insider ownership's) dengan jumlah saham yang dimiliki oleh pihak luar (outsider ownership's) (Suharli dan Rachpriliani, 2006).

Kepemilikan dari pihak luar (Outsider Ownership) tidak akan sering terlibat dalam kegiatan bisnis yang dilakukan oleh perusahaan. Kepemilikan pihak luar (Outsider Ownership) dapat mengamati perkembangan yang sedang terjadi dalam perusahaan, serta untuk mengetahui berapa peningkatan nilai pengembalian dari investasi yang ditanamkan. Konsentrasi kepemilikan pihak luar dalam penelitian ini diukur dengan besarnya persentase kepemilikan publik pada perusahaan yang terdaftar di BEI (Hilmi dan Ali, 2008).

\section{Hasil Penelitian dan Pembahasan}

Penelitian yang telah dilakukan secara statistik mengenai variabel-variabel yang mempengaruhi ketepatan waktu pelaporan keuangan menghasilkan beberapa temuan di antaranya:

1. Pengaruh profitabilitas terhadap ketepatan waktu pelaporan keuangan perusahaan.

Profitabilitas berpengaruh secara signifikan terhadap ketepatan waktu penyampaian pelaporan keuangan karena menunjuk- kan signifikansi 0,002 lebih kecil dari 0,05. Hal ini mendukung hipotesis 1 bahwa profitabilitas berpengaruh signifikan terhadap ketepatan waktu penyampaian pelaporan keuangan.

Hasil penelitian ini konsisten dengan penelitian yang dilakukan oleh Dwiyanti (2010), Permana (2012), dan Sukoco (2013) yang menyatakan bahwa profitabilitas berpengaruh secara signifikan terhadap ketepatan waktu pelaporan keuangan perusahaan. Semakin tinggi profit yang bisa dihasilkan oleh perusahaan maka perusahaan akan semakin cepat untuk menyampaikan laporan keuangannya, karena profit yang dihasilkan oleh perusahaan akan mengandung berita baik bagi perkembangan perusahaan. Semakin tinggi kemampuan perusahaan dalam menghasilkan laba maka perusahaan tersebut akan semakin tepat waktu dalam menyampaikan laporan keuangan.

2. Pengaruh ukuran perusahaan terhadap ketepatan waktu pelaporan keuangan perusahaan.

Ukuran perusahaan tidak berpengaruh terhadap ketepatan waktu pelaporan keuangan perusahaan karena menunjukkan signifikansi sebesar 0,466 lebih besar dari 0,05. Hasil penelitian ini tidak dapat mendukung hipotesis 2 yang mengungkapkan bahwa ukuran perusahaan berpengaruh signifikan terhadap ketepatan waktu penyampaian pelaporan keuangan. Ini berarti Hipotesis 2 tidak dapat diterima.

Hasil ini mendukung penelitian yang dilakukan oleh Melia (2012), dan Awaludin dan Peni (2012) yang menyatakan bahwa ukuran perusahaan tidak berpengaruh secara signifikan terhadap ketepatan waktu pelaporan keuangan perusahaan. Dikutip dari Wijayanti (2009) menyatakan bahwa ukuran perusahaan menunjukkan besarnya informasi yang ada dalam perusahaan, dan mencerminkan kesadaran pihak manajemen akan pentingnya informasi baik bagi pihak eksternal maupun internal perusahaan. Perusahaan besar cenderung akan melaporkan keuangan tepat waktu dibandingkan perusahaan kecil.

Penolakan ini bisa disebabkan karena 
perusahaan dengan skala besar atau kecil akan berusaha untuk menyampaikan laporan keuangan secara tepat waktu guna menghindari sanksi yang akan diterima jika terlambat dalam menyampaikan laporan keuangan. Namun hal tersebut akan tergantung pada tingkat kesadaran pihak manajemen yang ada dalam perusahaan.

\section{Pengaruh kepemilikan publik terhadap} ketepatan waktu pelaporan keuangan perusahaan.

Kepemilikan publik tidak berpengaruh terhadap ketepatan waktu pelaporan keuangan perusahaan karena menunjukkan signifikansi sebesar 0,783 lebih besar dari 0,05. Hasil penelitian ini tidak dapat mendukung hipotesis 3 yang mengungkapkan bahwa kepemilikan publik berpengaruh secara signifikan terhadap ketepatan waktu penyampaian laporan keuangan. Ini berarti Hipotesis 3 tidak dapat diterima.

Hasil penelitian ini konsisten dengan penelitian yang dilakukan oleh Melia (2012), Sukoco (2013), dan Suriyati (2013) yang menyatakan bahwa kepemilikan publik tidak mempengaruhi ketepatan waktu pelaporan keuangan perusahaan. Kepemilikan publik memberikan tekanan kepada pihak manajemen sehingga lebih berhati-hati dalam membuat laporan keuangan, sehingga pihak manajemen memerlukan waktu yang lebih lama untuk menyusun laporan keuangan yang mengakibatkan keterlambatan dalam penyampaian laporan keuangan.

\section{Saran untuk Penelitian Selanjutnya}

Berdasarkan keterbatasan yang telah dijelaskan, saran yang dapat penulis berikan untuk penelitian selanjutnya berkenaan dengan penelitian ini di antaranya:

1. Memperluas ruang lingkup penelitian, tidak hanya sebatas pada perusahaan sektor Property dan Real Estate, sebaiknya ditambah dengan perusahaan sektor lain yang terdaftar di BEI.

2. Memperpanjang periode tahun penelitian dan menggunakan tahun periode yang terbaru sehingga dapat menggambarkan kondisi perusahaan yang sebenarnya.

3. Menambahkan variabel penelitian yang dapat mempengaruhi ketepatan waktu pelaporan keuangan.

\section{Kesimpulan}

Tujuan dari penelitian ini adalah untuk menemukan bukti empiris mengenai faktorfaktor yang berpengaruh terhadap ketepatan waktu pelaporan keuangan pada perusahaan sektor Property dan Real Estate di Bursa Efek Indonesia. Hasil penelitian yang telah dilakukan, dapat ditarik kesimpulan sebagai berikut:

1. Pengujian dengan regresi logistik menunjukkan hasil bahwa variabel profitabilitas menunjukkan nilai probabilitas variabel sebesar 0,002 sehingga lebih kecil dari signifikansi 0,05 yang berarti Profitabilitas mempunyai pengaruh yang signifikan terhadap ketepatan waktu pelaporan keuangan.

2. Variabel ukuran perusahaan menunjukkan nilai probabilitas variabel sebesar 0,466 sehingga lebih besar dari signifikansi 0,05 yang berarti ukuran perusahaan tidak mempunyai pengaruh terhadap ketepatan waktu pelaporan keuangan.

3. Variabel kepemilikan publik menunjukkan nilai probabilitas variabel sebesar 0,783 sehingga lebih besar dari signifikansi 0,05 yang berarti kepemilikan publik tidak mempunyai pengaruh terhadap ketepatan waktu pelaporan keuangan.

\section{Implikasi}

Implikasi dalam penelitian ini bagi praktisi adalah dapat membantu para analisis keuangan, kreditur, dan pihak manajemen dalam menentukan ketepatan waktu pelaporan keuangan perusahaan. Sedangkan bagi akademisi hasil dari penelitian ini dapat dijadikan sebagai bahan ilmu pengetahuan dan dijadikan referensi untuk penelitian selanjutnya mengenai faktor-faktor yang dapat mempengaruhi ketepatan waktu pelaporan keuangan perusahaan. 


\section{Keterbatasan}

Penulis sepenuhnya menyadari bahwa dalam penelitian ini terdapat beberapa keterbatasan di antaranya:

1. Penelitian yang dilakukan hanya memfokuskan pada perusahaan sampel sektor property dan real estate tidak mengikutsertakan perusahaan sektor lain yang terdaftar di BEI.

2. Penelitian yang dilakukan untuk mengetahui variabel yang mempengaruhi ketepatan waktu perusahaan dalam menyampaikan laporan keuangan hanya dalam periode 4 tahun yaitu tahun 2011-2014.

3. Variabel yang digunakan untuk mengukur ketepatan waktu perusahaan hanya sebatas profitabilitas, ukuran perusahaan, dan kepemilikan publik.

\section{Daftar Pustaka}

Bronn, P. S., \& Vrioni, A. B. (2001). " Corporate Social Responbility and Causerelated Marketing: An Overview”. International Journal of Advertising, 20 (2): 207-222.

Chen, Y., Haizhong, W., \& Ke, Z. (2015). Consumer Processing Mindset As a Moderator of The Effect of Country of Origin Product Stereotype. Social Behavior and Personality, 43 (8):'1371-1384.

Cho, Y. (2014). "Different Shades of Green Consciousness: The Interplay of Sustainability Labeling and Environmental Impact on Product Evaluations". Journal of Business Ethics, 128: 73-82. (http://doi. org/10.1007/s10551-014-2080-4).

Cooper, D. R., \& Schindler, P. (2004). Business Research Methods. Ninth Edition. McGraw Hill Higher Education.

Dekhili, S., \& Achabou, M. A. (2014). "The Influence of the Country of Origin Ecological Image on Ecolabelled Product Evaluation: An Experimental Approach to the Case of the European Ecolabel".
Journal of Business Ethics: 1-18. (http:// doi.org/10.1007/s 10551-014-2261-1).

Ghazali, M., Said Othman, M., Zahiruddin Yahya, A., \& Sarif Ibrahim, M. (2008). Products and Country of Origin Effects: The Malaysian Consumers' Perception Introduction: Country of Origin Effect in The Global Market. International Review of Business Research Papers, 4 (2): 91102.

Hair, J. F., Black, B., \& Babin, B. (2006) Multivariate Data Analysis. 6th Edition. Prentice Hall.

Hoeffler, S., \& Keller, K. L. (2002). "Building Brand Equity Through Corporate Societal Marketing". Journal of Public Policy \& Marketing, 21 (1): 78-89.

Kim, H., \& Hall, M. L. (2015). Green Brand Strategies in the Fashion Industry: Leveraging Connections of the Consumer, Brand, and Environmental Sustainability. Sustainable Fashion Supply Chain Management: 31-41. (http://doi.org/10. 1007/978-3-319-12703-3).

Kim, H., \& Youn, S. (2008). "Antecedents of Consumer Attitudes toward Cause-Related Marketing”. Journal of Advertising Research, 48 (1): 123-137. (http://doi. org/10.2501/S0021849908080136).

Kim, J. E., \& Johnson, K. K. P. (2013). "The Impact of Moral Emotions on Cause-Related Marketing Campaigns: A Cross-Cultural Examination". Journal of Business Ethics, 112 (1): 79-90. (http:// doi.org/10.1007/s10551-012-1233-6).

Landreth, S. (2002). For a Good Cause: The Effects of Cause Importance, Cause Proximity, Congruency and Participation Effort on Consumers' Evaluation of CausRelated Marketing. Lousiana State University.

Strahle, J., \& Koksal, D. (2015). “Impact of 
Brand and Country Image on The Perception of Sustainability in The Fashion Business". International Journal of Business and Commerce, 5 (01): 25-28.
Webb, D. J., \& Mohr, L. A. (1998). “A Typology of Consumer Responses to CauseRelated Marketing from Skeptics to Socially Concerned". Journal of Public Policy \& Marketing, 17 (2): 226-238. 